The Turkish Online Journal of Design, Art and Communication - TOJDAC

ISSN: 2146-5193, March 2018 Special Edition, p. 434-443

\title{
METHODICAL APPROACH TO EVALUATING THE EFFECTIVENESS OF STATE SUPPORT IN THE FIELD OF DEVELOPMENT OF AGRICULTURAL CONSUMER COOPERATIVE
}

\author{
T.A. Dozorova ${ }^{1}$, N.R. Alexandrova², V.M. Sevastyanova ${ }^{3}$, N.A.Utmanova ${ }^{4}$, \\ 1Professor, Doctor of Economics, FSBEI HE Ulyanovsk State Agricultural University named after \\ P.A. Stolypin, \\ ${ }^{2}$ Associate Professor, Candidate of Economic Sciences, FSBEI HE Ulyanovsk State Agricultural \\ University named after P.A. Stolypin, \\ ${ }^{3}$ Senior Lecturer, FSBEI HE Ulyanovsk State Agricultural University named after P.A. Stolypin, \\ ${ }^{4}$ Assistant, FSBEI HE Ulyanovsk State Agricultural University named after P.A. Stolypin \\ The reported research was funded by Russian Foundation for Basic Research and the government \\ of the Ulyanovsk region of the Russian Federation, grant № 18-410-730019
}

\begin{abstract}
The system of agricultural consumer cooperation is a dynamically changing system, which is transformed in time and space in the process of socio-economic development, so the assessment of state support for agricultural consumer cooperatives should be based on methodological approaches that allow to take into account the dynamics and statics in the quantitative and qualitative characteristics of the processes of development of agricultural consumer cooperation.

The aim of the study is to develop tools to assess the effectiveness of state support for the activities of agricultural consumer cooperatives. It is revealed that to assess the effectiveness of budget allocations aimed at the development of agricultural consumer cooperation, a specially developed system of criteria reflecting the various aspects of the effectiveness of consumer cooperatives is necessary. To this end, the authors developed and proposed a methodological approach to assessing the effectiveness of state support for agricultural consumer cooperatives, based on the calculation of individual and group indices in two blocks: the effectiveness of agricultural consumer cooperatives and the effectiveness of the use of grant funds. The paper presents the approbation of the proposed methodological approach to assess the effectiveness of state support of agricultural consumer cooperatives.
\end{abstract}

The approach developed by the authors to evaluate the effectiveness of state support in the field of the development of agricultural consumer cooperative allows to analyze the degree of achievement of results in the context of the use of budget allocations on the basis of the matrix approach. The advantages of the methodology developed by the authors are: objective assessment of the work of agricultural consumer cooperatives from the point of view of the socio-economic nature of cooperation; ability to compare the level of efficiency of state support for agricultural consumer cooperatives of a particular municipality, the region and the country as a whole; elimination of subjective factors in assessing the diverse characteristics of consumer cooperatives; use of official accounting (financial) statements of consumer cooperation organizations as a source of information.

Keywords: agricultural cooperatives, consumer cooperatives, criteria of effectiveness, state support, evaluation methods, methodological approach, integral method, subsidies 


\section{INTRODUCTION}

Focusing on the Procedure for the development, implementation and evaluation of the effectiveness of state programs of the Russian Federation (approved by the Government of the Russian Federation on August 2, 2010, enactment № 588), Guidelines for the development and implementation of these programs (approved by the order of the Ministry of economic development of Russia dated December 22, 2010 № 670), the assessment of the effectiveness of state support for the development of agricultural consumer cooperation provides the need for the assessment of:

- degree of achievement of the goals and objectives of the state program by comparing the actual values of the target indicators of the state program and their planned values;

- degree of compliance with the planned budgetary allocations for financial support of implementation of the state program and efficient use of budgetary allocations for the financial support of implementation of the state program by comparing planned and actual budgetary allocations for the financial support of implementation of the state program;

- the degree of implementation of the state program activities on the basis of comparison of the expected and actually obtained direct results of the state program activities.

\section{MATERIALS AND METHODS}

Since 2016, state support for the development of agricultural consumer cooperation of the region has been carried out within the framework of the state program of Ulyanovsk region "Development of agriculture and regulation of markets for agricultural products, raw materials and food in Ulyanovsk region" for 2014-2020. The method of assessing the effectiveness of the State program is presented in the Annex of the designated program. According to this method, the effectiveness of the state program as a whole is estimated based on the degree of achievement of the set values of each of the main target indicators of the state program both for the years in relation to the previous year and the cumulative result to the base year. The degree of achievement of the goals of the state program $\left(C_{d}\right)$ according to the target indicator, the desired trend of change of which is an increase in its value, is determined by the formula (1):

$$
C_{d}=\frac{Z_{f}}{Z_{p}} \times 100 \%
$$

where $Z_{f}$ - the actual value of the target indicator of the state program; $Z_{p}-$ the planned value of the target indicator of the state program.

The degree of compliance of the actual volume of budgetary allocations of the regional budget of Ulyanovsk region for financial support of implementation of the state program to their planned volume $\left(C_{f}\right)$ is determined by the formula (2):

$$
C_{f}=\frac{F_{f}}{F_{p}} \times 100 \%
$$

where $F_{f}$ - the actual amount of budgetary allocations of the regional budget of Ulyanovsk region

for financial support of implementation of the state program aimed at the implementation of the state program activities; $F_{p}$ - the planned amount of budgetary allocations of the regional budget of Ulyanovsk region for the financial support of implementation of the state program for the corresponding reporting period.

Based on the evaluation of the state program, the following conclusions can be made: if the value of the state program evaluation is less than $50 \%$, the implementation of the state program is

Submit Date: 09.01.2018, Acceptance Date: 23.02.2018, DOI NO: 10.7456/1080MSE/151

Research Article - This article was checked by Turnitin

Copyright (C) The Turkish Online Journal of Design, Art and Communication 
considered ineffective; from 50 to $80 \%$ - moderately effective; from 80 to $100 \%$-effective; more than $100 \%$ - highly effective (table 1 ).

Table 1 - Evaluation of the effectiveness of state support for the development of agricultural consumer cooperation in the framework of the state program of Ulyanovsk region "Development of agriculture and regulation of markets for agricultural products, raw materials and food in Ulyanovsk region" for 2014-2020

\begin{tabular}{|c|c|c|c|c|c|c|}
\hline \multirow[b]{2}{*}{ Target indicators of the program } & \multicolumn{3}{|c|}{$2016 г$. } & \multicolumn{3}{|c|}{2017 г. } \\
\hline & $\begin{array}{l}\text { Planne } \\
\mathrm{d} \\
\text { amount }\end{array}$ & $\begin{array}{l}\text { Actual } \\
\text { amoun } \\
\mathrm{t}\end{array}$ & $\begin{array}{l}\text { Degree of } \\
\text { achievemen } \\
\quad \text { t or } \\
\text { compliance }\end{array}$ & $\begin{array}{l}\text { Planne } \\
\mathrm{d} \\
\text { amount }\end{array}$ & $\begin{array}{l}\text { Actual } \\
\text { amoun } \\
\mathrm{t}\end{array}$ & $\begin{array}{l}\text { Degree of } \\
\text { achievemen } \\
\text { t or } \\
\text { compliance }\end{array}$ \\
\hline $\begin{array}{l}\text { The number of agricultural consumer } \\
\text { cooperatives that have developed } \\
\text { their material and technical base with } \\
\text { the help of state support }\end{array}$ & 3 & 3 & 1,00 & 5 & 8 & 1,60 \\
\hline $\begin{array}{l}\text { Increased sales of milk collected by } \\
\text { agricultural consumer cooperatives } \\
\text { from agricultural producers, } \\
\text { compared to the last year, } \%\end{array}$ & 1,2 & 1,12 & 0,93 & 1,2 & 1,15 & 0,96 \\
\hline $\begin{array}{l}\text { The number of created new } \\
\text { permanent jobs in agricultural } \\
\text { consumer cooperatives, that have } \\
\text { developed their material and } \\
\text { technical base with the help of state } \\
\text { support, units. }\end{array}$ & 18 & 20 & 1,11 & 30 & 31 & 1,03 \\
\hline $\begin{array}{l}\text { Grants in the form of subsidies to } \\
\text { agricultural consumer cooperatives } \\
\text { for the development of material and } \\
\text { technical base, thousand rubles. }\end{array}$ & 15000 & 11898 & 0,79 & 2500 & 5000 & 2,00 \\
\hline $\begin{array}{l}\text { Coefficient of assessment of the state } \\
\text { program }\end{array}$ & - & - & 0,96 & - & - & 1,40 \\
\hline
\end{tabular}

According to the data obtained in 2016, the implementation of the state support for the development of agricultural consumer cooperation in the framework of the State program is recognized as effective, in 2017 - highly effective.

Since 2017 the state support for agricultural consumer cooperatives of Ulyanovsk region is carried out within the framework of the law "On measures of state support for agricultural consumer cooperatives, consumer societies and certain categories of citizens conducting a personal subsidiary farm in Ulyanovsk region". According to the law, the number of target indicators has increased to 16 (table 2).

The presented methodology only uses the assessment of the degree of achievement of results, but it does not compare the results with the budgetary allocations for the implementation of the program. As a result, there is a need to develop a new method of assessing the effectiveness of state support for agricultural cooperatives.

Table 2-Target indicators of Priority project "Development of the consumer cooperation system in Ulyanovsk region» 


\begin{tabular}{|c|c|c|c|c|}
\hline \multirow{2}{*}{ Target indicators of the project } & \multirow{2}{*}{$\begin{array}{l}\text { Base } \\
\text { value } \\
2016\end{array}$} & \multicolumn{3}{|c|}{ Periods, year } \\
\hline & & 2017 & 2018 & 2019 \\
\hline $\begin{array}{l}\text { The number of working agricultural consumer cooperatives } \\
\text { in the region, units. }\end{array}$ & 25 & 34 & 43 & 48 \\
\hline $\begin{array}{l}\text { The number of agricultural consumer cooperatives-grantees } \\
\text { within the state program of agricultural development, units. }\end{array}$ & 3 & 3 & 5 & 7 \\
\hline $\begin{array}{l}\text { The volume of annual financing for the modernization of } \\
\text { the material and technical base of agricultural consumer } \\
\text { cooperatives, million rubles (regional budget) }\end{array}$ & 5,0 & 8,0 & 16,0 & 32,0 \\
\hline $\begin{array}{l}\text { Employment of rural citizens in the system of consumer } \\
\text { cooperative, people }\end{array}$ & 5800 & 7400 & 9400 & 10000 \\
\hline $\begin{array}{l}\text { The number of private farms that are members of } \\
\text { cooperatives, people. }\end{array}$ & 3300 & 3500 & 4000 & 5000 \\
\hline $\begin{array}{l}\text { Increase in the volume of milk sold by members of } \\
\text { cooperatives through the system of consumer cooperation, } t\end{array}$ & 10000 & 11000 & 13000 & 15000 \\
\hline The volume of subsidies for 1 liter of milk, million rubles. & 0 & 22,5 & 34,5 & 50,0 \\
\hline $\begin{array}{l}\text { Increase in the volume of meat sold by members of } \\
\text { cooperatives through the system of consumer cooperation, } t\end{array}$ & 6,0 & 8,0 & 10,0 & 12,0 \\
\hline $\begin{array}{l}\text { Number of cattle, acquired by private subsidiary farms- } \\
\text { members of cooperatives with the help of state support } \\
\text { measures, head }\end{array}$ & 0 & 150 & 270 & 390 \\
\hline $\begin{array}{l}\text { The volume of subsidies issued for the purchase of } \\
\text { livestock, million rubles. }\end{array}$ & 0 & 3,75 & 7,56 & 11,7 \\
\hline $\begin{array}{l}\text { The number of mini-dairy farms built by personal } \\
\text { subsidiary farms-members of cooperatives with the help of } \\
\text { state support measures, units. }\end{array}$ & 0 & 9 & 15 & 20 \\
\hline $\begin{array}{l}\text { Subsidies for the construction of mini-dairy farms, million } \\
\text { rubles. }\end{array}$ & 0 & 1,1 & 2,5 & 4,7 \\
\hline $\begin{array}{l}\text { Increase in the volume of vegetables sold by members of } \\
\text { cooperatives through the system of consumer cooperation, } t\end{array}$ & 3180 & 4000 & 4500 & 5800 \\
\hline $\begin{array}{l}\text { The number of mini-greenhouses built by personal } \\
\text { subsidiary farms by members of cooperatives with the help } \\
\text { of state support measures, units. }\end{array}$ & 0 & 3 & 5 & 10 \\
\hline $\begin{array}{l}\text { Subsidies for the construction of mini-greenhouses, million } \\
\text { rubles }\end{array}$ & 0 & 0,03 & 0,055 & 0,12 \\
\hline $\begin{array}{l}\text { Modernization of material and technical base of consumer } \\
\text { societies, million rubles }\end{array}$ & 4,5 & 4,5 & 4,5 & 6,5 \\
\hline
\end{tabular}

\section{RESULTS}

It is proposed to assess the effectiveness of state support for agricultural consumer cooperatives using single and group indices calculated on the following private indicators: 


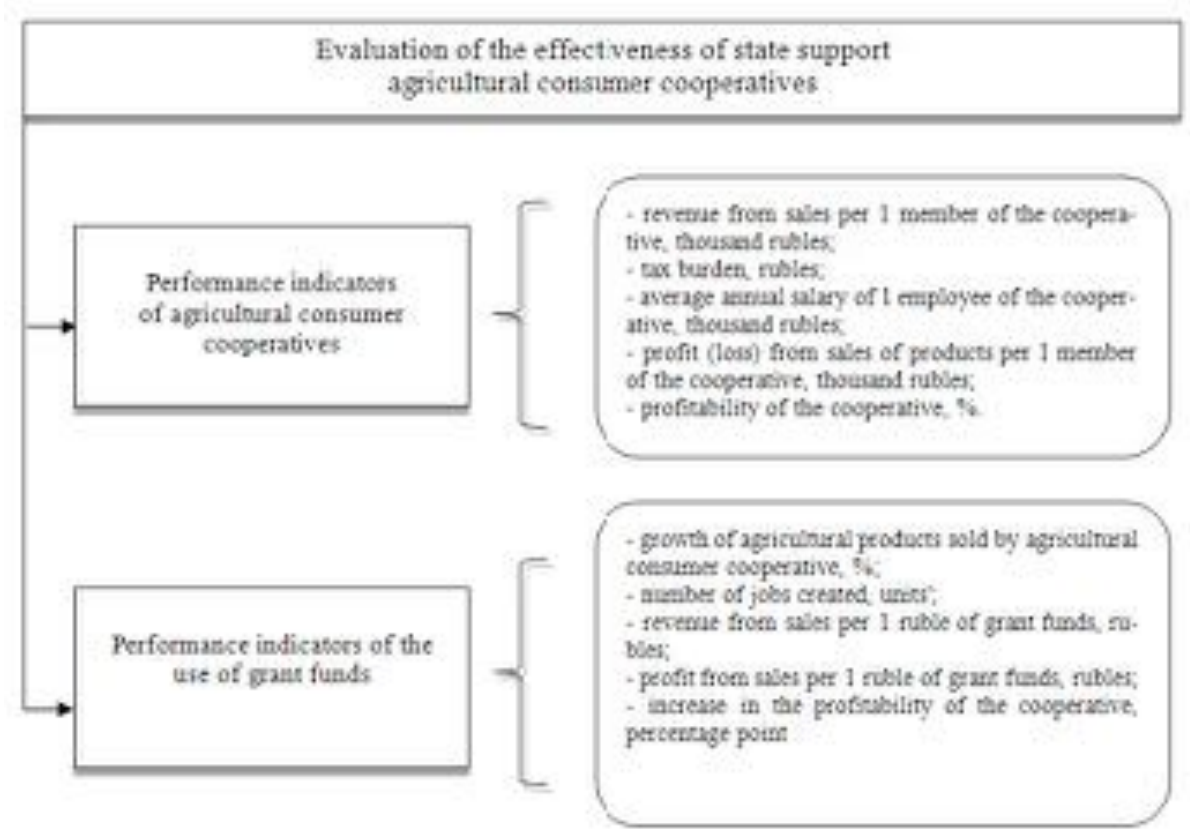

Figure 1 - Performance Indicators of state support of agricultural consumer cooperatives

1. Performance indicators of agricultural consumer cooperatives:

- revenue from sales per 1 member of the cooperative, thousand rubles.;

- tax burden, RUB.;

- average annual salary of 1 employee of the cooperative, thousand rubles.;

- profit (loss) from the sale of products per 1 member of the cooperative thousand rubles.;

- profitability of the cooperative, $\%$.

2. Performance indicators of the use of grant funds:

- growth of agricultural products sold by agricultural consumer cooperative, \%;

- number of jobs created, units;

- revenue from sales per 1 RUB of grant funds, RUB. ;

- profit from the sale of products per 1 RUB. of grant funds, RUB. ;

- increase in profitability of the cooperative, p.p. (Fig. 1).

\section{Discussion}

Testing of the proposed methodology will be carried out on the basis of the data of the Register of agricultural consumer cooperatives that received a grant in the form of a subsidy for the development of material and technical base in 2017 as of 01 October 2017. Initial data for the evaluation of the effectiveness of state support of agricultural consumer cooperatives are presented in table 3, individual and group indices of private indicators - in table 4.

Table 3-Initial data to assess the effectiveness of state support for agricultural consumer cooperatives (according to the Register of agricultural consumer cooperatives, which received a grant in the form of a subsidy for the development of material and technical base in 2017, as of 01 October 2017.)

\begin{tabular}{|c|c|c|c|c|c|c|}
\hline Indicators & $\begin{array}{c}\text { ACSSC } \\
\text { «Fabrika } \\
»\end{array}$ & $\begin{array}{c}\text { ACSSC } \\
\text { «erspektiva } \\
»\end{array}$ & $\begin{array}{c}\text { ACSC } \\
\text { «Sodeystviye } \\
»\end{array}$ & $\begin{array}{c}\text { ACSSC } \\
\text { «Moloko } \\
» »\end{array}$ & $\begin{array}{c}\text { ACSC } \\
\text { «Progress } \\
»\end{array}$ & $\begin{array}{c}\text { ACSSC } \\
\text { «Myasno } \\
\text { y dvor» }\end{array}$ \\
\hline \multicolumn{7}{|c|}{ Performance indicators of agricultural consumer cooperatives } \\
\hline $\begin{array}{l}\text { Revenue from sales of } \\
\text { products per } 1 \text { member } \\
\text { of the cooperative, } \\
\text { thousand rubles. }\end{array}$ & 271,05 & 91,61 & 93,47 & 155,50 & 107,15 & 300,93 \\
\hline
\end{tabular}

Submit Date: 09.01.2018, Acceptance Date: 23.02.2018, DOI NO: 10.7456/1080MSE/151

Research Article - This article was checked by Turnitin

Copyright (C) The Turkish Online Journal of Design, Art and Communication 
The Turkish Online Journal of Design, Art and Communication - TOJDAC

ISSN: 2146-5193, March 2018 Special Edition, p. 434-443

\begin{tabular}{|l|c|c|c|c|c|c|}
\hline Tax burden, RUB & 21,07 & 55,49 & 145,44 & 12,11 & 699,80 & 27,73 \\
\hline $\begin{array}{l}\text { Average annual wages } \\
\text { per 1 employee of the } \\
\text { cooperative, thousand } \\
\text { rubles }\end{array}$ & 72,0 & 109,1 & 81,1 & 176,6 & 31,1 & 55,7 \\
\hline $\begin{array}{l}\text { Profit from sales per 1 } \\
\text { m e m b r of th e } \\
\text { cooperative, thousand } \\
\text { rubles }\end{array}$ & 6,23 & 2,01 & 1,10 & 4,82 & 1,69 & 50,29 \\
\hline $\begin{array}{l}\text { Profitability of the } \\
\text { cooperative, \% }\end{array}$ & 2,3 & 2,2 & 1,18 & 3,2 & 1,6 & 16,7 \\
\hline $\begin{array}{l}\text { Growth of agricultural } \\
\text { product s o ld by } \\
\text { agricultural consumer } \\
\text { cooperative, \% }\end{array}$ & 2,3 & 16 & 0 & 29 & 43 & 69,67 \\
\hline $\begin{array}{l}\text { Number of created } \\
\text { jobs, units. }\end{array}$ & 1 & 1 & 0 & 2 & 1 & 0 \\
\hline $\begin{array}{l}\text { Revenue from sales per } \\
\text { 1 RUB of grant funds, } \\
\text { RUB. }\end{array}$ & 3,08 & 11,71 & 33,31 & 9,31 & 23,41 & 3,58 \\
\hline $\begin{array}{l}\text { Net profit per 1 RUB } \\
\text { of grant funds, RUB }\end{array}$ & 0,07 & 0,17 & 0,39 & 0,29 & 0,37 & 0,60 \\
\hline $\begin{array}{l}\text { Increase in profitability } \\
\text { of the cooperative, p. } \\
\text { p. }\end{array}$ & 2,3 & 0,2 & $-1,29$ & $-1,9$ & 1,0 & 15,9 \\
\hline
\end{tabular}

Table 4 - Individual and group indices of effectiveness of state support of agricultural consumer cooperatives

\begin{tabular}{|c|c|c|c|c|c|c|}
\hline Indicators & $\begin{array}{l}\text { ACSSC } \\
\ll \text { Fabrika } \\
»\end{array}$ & $\begin{array}{c}\text { ACSSC } \\
\text { «Perspektiva } \\
»\end{array}$ & $\begin{array}{c}\text { ACSC } \\
\text { «Sodeystviye } \\
»\end{array}$ & $\begin{array}{l}\text { ACSSC } \\
\text { «Moloko } \\
\quad »\end{array}$ & $\begin{array}{c}\text { ACSC } \\
\ll \text { Progress } \\
»\end{array}$ & $\begin{array}{c}\text { ACSSC } \\
\text { «Myasno } \\
\text { y dvor» }\end{array}$ \\
\hline \multicolumn{7}{|c|}{ Performance indices of agricultural consumer cooperatives } \\
\hline $\begin{array}{l}\text { Single indices: sales } \\
\text { revenue per } 1 \text { member } \\
\text { of the cooperative }\end{array}$ & 0,901 & 0,304 & 0,311 & 0,517 & 0,356 & 1,000 \\
\hline tax burden & 0,030 & 0,079 & 0,208 & 0,017 & 1,000 & 0,040 \\
\hline $\begin{array}{l}\text { average annual salary } \\
\text { per } 1 \text { employee of the } \\
\text { cooperative }\end{array}$ & 0,408 & 0,618 & 0,459 & 1,000 & 0,176 & 0,315 \\
\hline $\begin{array}{l}\text { profit from sales per } 1 \\
\text { m e } m \text { b e r of } t h \text { e } \\
\text { cooperative }\end{array}$ & 0,124 & 0,040 & 0,022 & 0,096 & 0,034 & 1,000 \\
\hline
\end{tabular}

Submit Date: 09.01.2018, Acceptance Date: 23.02.2018, DOI NO: 10.7456/1080MSE/151

Research Article - This article was checked by Turnitin

Copyright (C) The Turkish Online Journal of Design, Art and Communication 
The Turkish Online Journal of Design, Art and Communication - TOJDAC

ISSN: 2146-5193, March 2018 Special Edition, p. 434-443

\begin{tabular}{|l|c|c|c|c|c|c|}
\hline $\begin{array}{l}\text { profitability of the } \\
\text { cooperative }\end{array}$ & 0,138 & 0,132 & 0,071 & 0,192 & 0,096 & 1,000 \\
\hline $\begin{array}{l}\text { Group performance } \\
\text { index of consumer } \\
\text { cooperatives }\end{array}$ & 0,320 & 0,235 & 0,214 & 0,364 & 0,332 & 0,671 \\
\hline \multicolumn{2}{|c|}{ Indexes of efficiency of use of grant funds } & 0,000 & 0,416 & 0,617 & 1,000 \\
\hline $\begin{array}{l}\text { Individual indices: } \\
\text { growth of agricultural } \\
\text { products sold by } \\
\text { agricultural consumer } \\
\text { cooperative }\end{array}$ & 0,033 & 0,230 & 0,000 & 1,000 & 0,500 & 0,000 \\
\hline $\begin{array}{l}\text { number of created jobs } \\
\text { revenue from sales of } \\
\text { goods per 1 RUB. of } \\
\text { grant funds }\end{array}$ & 0,092 & 0,352 & 1,000 & 0,279 & 0,703 & 0,107 \\
\hline $\begin{array}{l}\text { net profit per 1 RUB of } \\
\text { grant funds }\end{array}$ & 0,179 & 0,436 & 1,000 & 0,744 & 0,949 & 1,538 \\
\hline $\begin{array}{l}\text { in c r a s e in the } \\
\text { profitability of the } \\
\text { cooperative }\end{array}$ & 0,145 & 0,013 & $-0,081$ & $-0,119$ & 0,063 & 1,000 \\
\hline $\begin{array}{l}\text { Group in d e of of } \\
\text { efficiency of use of } \\
\text { grant funds }\end{array}$ & 0,190 & 0,306 & 0,384 & 0,464 & 0,566 & 0,729 \\
\hline
\end{tabular}

On the basis of the obtained data, it is possible to construct a two-dimensional matrix of values of group indices for each agricultural consumer cooperative, that received state support in the form of subsidies. To determine the position of the consumer cooperative, the value of the group performance index of agricultural consumer cooperatives should be plotted on the abscissa, on the ordinate-the group efficiency index of the use of grant funds (Fig. 2).

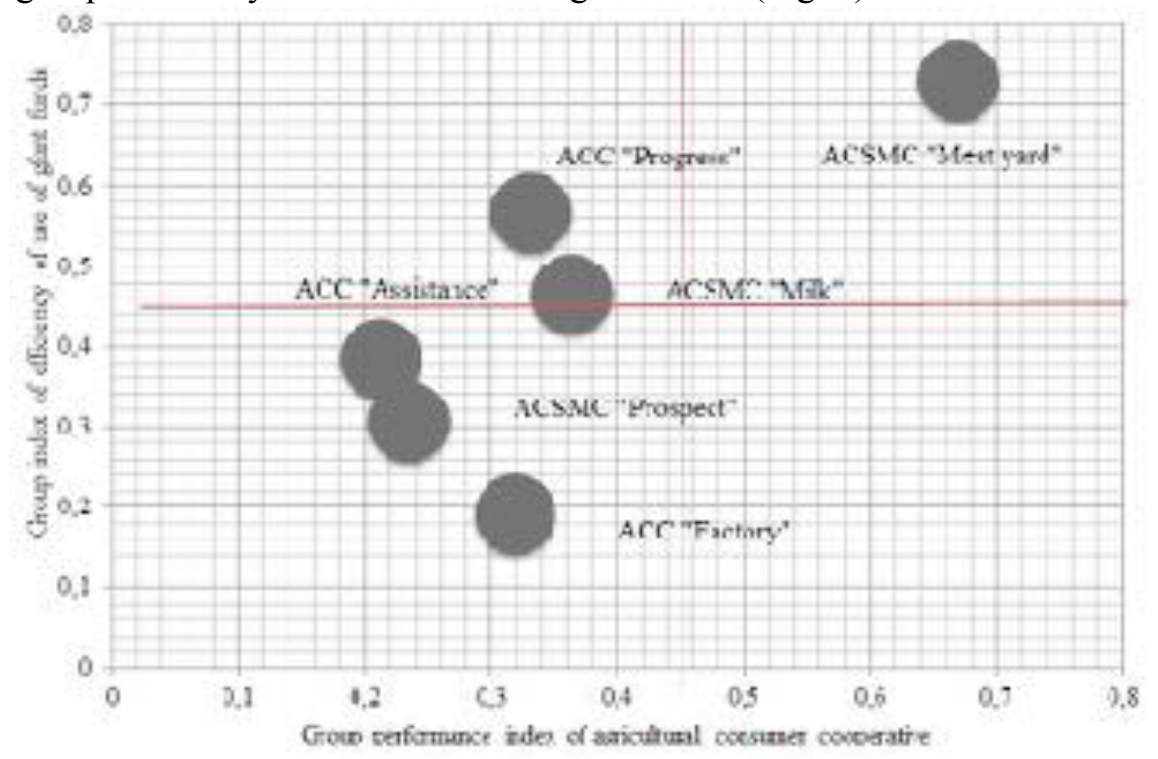

Figure 2 - Matrix of the efficiency of state support of agricultural consumer cooperatives of

Submit Date: 09.01.2018, Acceptance Date: 23.02.2018, DOI NO: 10.7456/1080MSE/151

Research Article - This article was checked by Turnitin

Copyright (C) The Turkish Online Journal of Design, Art and Communication 
Ulyanovsk region, according to the register on 01.10.2017.

It is advisable to determine the boundaries of sectors on the basis of calculating the average value of group performance indices and the effectiveness of the use of grant funds.

All agricultural consumer cooperatives are grouped into four segments based on vertical and horizontal boundaries. The value of the vertical boundary ( $)$ is determined by the formula (3):

$$
\text { vertical boundary }\left(g_{2}\right) \text { is determined by the formula (3): }
$$

where $I_{\max z}$ - the maximum value of the group performance index in the study totality, $I_{\min z}$ - the minimum value of the group performance index in the study totality.

The value of the horizontal boundary in the matrix of the efficiency of state support of agricultural consumer cooperatives is determined in the same way.

The construction of the matrix allowed us to identify four types of agricultural consumer cooperatives by the level of efficiency of state support (table. 5).

Table 5 - Typology of agricultural consumer cooperatives by the level of efficiency of state support (according to the Register on 01.10.2017).)

\begin{tabular}{|l|l|}
\hline \multicolumn{1}{|c|}{ Type of agricultural consumer cooperative } & \multicolumn{1}{|c|}{$\begin{array}{c}\text { Name of the agricultural consumer } \\
\text { cooperative }\end{array}$} \\
\hline $\begin{array}{l}\text { With a high level of performance and efficiency of state } \\
\text { support }\end{array}$ & ACSSC «Myasnoy dvor» \\
\hline $\begin{array}{l}\text { With a high level of performance, but low efficiency of } \\
\text { state support }\end{array}$ & $\begin{array}{l}\text { ACSC «Progress», } \\
\text { ACSSC «Moloko» }\end{array}$ \\
\hline $\begin{array}{l}\text { With a low level of performance, but high efficiency of } \\
\text { state support }\end{array}$ & \\
\hline $\begin{array}{l}\text { With a low level of performance and efficiency of state } \\
\text { support }\end{array}$ & $\begin{array}{l}\text { ACSC «Sodeystviye», } \\
\text { ACSSC «Perspektiva», } \\
\text { ACSSC «Fabrika» }\end{array}$ \\
\hline
\end{tabular}

The analysis showed that only one agricultural consumer cooperative is characterized by a high degree of acquisition of state subsidies - ACSSC «Myasnoy dvor». Despite the lack of additional jobs created by the acquisition of grant funds, agricultural consumer cooperative is characterized by a significant increase in agricultural products sold by the cooperative, and the profitability of activities.

\section{CONCLUSION}

The proposed method of assessing the effectiveness of state support in the field of the development of agricultural consumer cooperation allows on the basis of a matrix approach to analyze the degree of achievement of results in the context of the use of budgetary allocations.

The advantages of the method developed by the authors are:

- objective evaluation of agricultural consumer cooperatives from the point of view of the socioeconomic nature of cooperation;

- possibility of comparing the level of effectiveness of state support of agricultural consumer cooperatives of a particular municipality, region and the country as a whole;

- elimination of subjective factors in assessing the diverse characteristics of consumer cooperatives;

- use of official accounting (financial) statements of consumer cooperation organizations as a source of information.

A comprehensive assessment of the effectiveness of state support for agricultural consumer cooperation on the proposed methodology is advisable to regularly assess the state of agricultural

Submit Date: 09.01.2018, Acceptance Date: 23.02.2018, DOI NO: 10.7456/1080MSE/151

Research Article - This article was checked by Turnitin

Copyright (C) The Turkish Online Journal of Design, Art and Communication 
The Turkish Online Journal of Design, Art and Communication - TOJDAC

ISSN: 2146-5193, March 2018 Special Edition, p. 434-443

cooperation in the region and to develop ways to adjust the legal, economic and social conditions for the long-term development of cooperation.

\section{Conflict of interest}

The authors confirm that the presented data do not contain a conflict of interest.

\section{REFERENCES}

1. Yanbykh, R.G. Trends in the development of agricultural consumer cooperatives in Russia / R.G. Yanbykh // Economics of agriculture of Russia. - 2017. - № 11. - P. 77-83.

2. Lukinykh, M. I. The theory of peasant cooperation N. G. Chernyshevsky / M. I. Lukinykh // Materials of VII International scientific-practical conference "World science: problems and innovations». - Penza: Science and education, 2017 - P. 104-108.

3. Gubin, V.V. To the question about criteria of efficiency estimation of organizations of consumer cooperation / V.V. Gubin // Management of economic systems: electronic scientific journal. - 2012. - № 4 (40). - P.68.

4. Auer, M. Sozialmarketing also unternehmerishes Erfolgkonzept / M. Auer. - Frankfurt: Dftz Verlag, 1992. - p. 22-38.

5. Frederick, D. A., Co-ops 101: An Introduction to Cooperatives / D. Frederick // Washington, D. C., Rural Business-Cooperative Service (USDA), - June 1997. -10 p.

6. Staatz, J.M. Farmer Cooperative Theory: Recent Developments, USDA, ACS Research Report 84. $-1989 .-36 \mathrm{p}$.

7. Le Vay, C. Agricultural Cooperative Theory: A Review / C. Le Vay // Journal of Agricultural Economics. - 1983. - № 34. - P. 1-44.

8. Maltseva, I. S. Cooperation and agro-industrial integration: textbook / I. S. Maltseva. Syktyvkar: Syktyvkar forest Institute, 2013. - 88 p.

9. Lerman, Zvi and Parliament, Claudia. Agricultural Cooperatives in the U.S. and Israel. Printed by Create Space, An Amazon.com Company. - 2017. - 106 p.

10. Nourse, E.G. The Economic Philosophy of Cooperation / E.G. Nourse // American Economic Review. - 1922. - № 12(4). - P. 577-597.

11. Enke, S. Consumer Cooperatives and Economic Efficiency / S. Enke, // American Economic Review. - 1945. - № 35(1). - P. 148-55.

12. Helmberger, P. Cooperative Enterprise as a Structural Dimension of Farm Markets / P. Helmberger // Journal of Farm Economics. - 1964. - № 46 (3). - P. 603-617.

13. Guidelines for the development of cooperation (student and agricultural consumer cooperatives) / edited by O. P. Chekmarev, E. V. Averyanova - St. Petersburg.: SpbSAU, 2013. $248 p$.

14. Larinina, Tatyana Ivanovna. Formation and development of consumer cooperation in the agricultural sector of the Kirov region: thesis ... candidate of economic Sciences: 08.00.05 / Larinina Tatyana Ivanovna; [North-West research Institute of Economics and organization of agriculture of RAASJ. - Kirov, 2009. - 194 p.

15. Dozorova T.A. The theory of consumer cooperation of the early twentieth century / T.A. Dozorova // Vestnik of Ulyanovsk state agricultural Academy. - 2011. - № 2 (14). - P. 142-146.

16. Chayanov, A.V. Main ideas and forms of organization of agricultural cooperation / A.V. Chayanov. - M.: Nauka, 1987. - 357 p.

17. Lilimberg, Svetlana Ivanovna. Increase of the efficiency of development of rural consumer cooperation: thesis ... candidate of economic Sciences: 08.00.05 / Lilimberg Svetlana Ivanovna. Chelyabinsk, 2017. - 210p.

18. Korobeynikova, E.V. System assessment of the efficiency of consumer cooperation / E.V. Korobeynikova // Economic problems of regions and branch complexes. - 2009. - № 4 (32). - P. 371-374.

19. Kutayeva, T.N. Assessing method of the economic efficiency of services provided by consumer cooperation organizations / T.N. Kutayeva, N.T. Savrukov, A.A. Kutayev // Fundamental study. 2014. - № 12-10. - P. 2169-2173.

Submit Date: 09.01.2018, Acceptance Date: 23.02.2018, DOI NO: 10.7456/1080MSE/151

Research Article - This article was checked by Turnitin

Copyright (C) The Turkish Online Journal of Design, Art and Communication 
ISSN: 2146-5193, March 2018 Special Edition, p. 434-443

20. Sidorkina, M.Y. Evaluation model of agricultural consumer cooperatives/ M.Y. Sidorkina, O.E. Ivanova // Modern control technologies. - 2016. - № 10 (70). Access mode: http://sovman.ru/ article/7004/ date (20.04.2018).

21. Krutikov, V. K., Kuzmina, Y. V. Strategy for the development of agricultural consumer cooperatives network / V. K. Krutikov, Y. V. Kuzmina. - M.: Noosfera, 2010. - 203 p.

22. Buzdalov, I.N. Theory and legal support of cooperation in modern Russia / I.N. Buzdalov // State and prospects of consumer cooperation development in Russia. - Yaroslavl-Moscow: Chancellor. - 2016. - P. 54-64. 